\title{
The power ranking of the members of the Agricultural Committee of the European Parliament
}

\author{
Imre Fertố, ${ }^{\dagger}+\dagger$, László Á. Kóczy ${ }^{\dagger, \ddagger}$, Attila Kovács ${ }^{\S, *}$ and \\ Balázs R. Sziklai ${ }^{\dagger} * *$
}

${ }^{\dagger}$ Institute of Economics, Centre for Economic and Regional Studies, Budapest, Hungary; ${ }^{*}$ Department of Finance, Budapest University of Technology and Economics, Hungary; ${ }^{\S}$ Károli Gáspár University of the Reformed Church, Budapest, Hungary; ${ }^{* *}$ Department of Operations Research and Actuarial Sciences, Corvinus University of Budapest, Hungary; ${ }^{\dagger \dagger}$ Kaposvár University, Kaposvár, Hungary

Received August 2018; final version accepted March 2020

Review coordinated by Jack Peerlings

\begin{abstract}
We aim to identify the most influential members of the Agricultural Committee of the European Parliament (COMAGRI). Unlike previous studies that were based on case studies or interviews with stakeholders, we analyse the voting power of MEPs using a spatial Banzhaf power index. We identify critical members: members whose votes are necessary to form winning coalitions. We found that rapporteurs, EP group coordinators and MEPs from countries with high relative Committee representations, such as Ireland, Poland or Romania are powerful actors. Italy emerges as the most influential member state, while France seems surprisingly weak.
\end{abstract}

Keywords: European Parliament, Common Agricultural Policy, voting games, Banzhaf index, voting game over a convex geometry

JEL code: D72, Q18

\section{Introduction}

Discussion about the content as well as the future of the Common Agricultural Policy (CAP) of the European Union (EU) has been high on the political agenda in the last decades and generated much academic interest as well. CAP reforms have been subject to comprehensive analysis both from political and policy aspects. In his landmark book, 'The Perfect Storm' on the 2003 Fischler reform, Swinnen (2008) shares the view that this has been the most 
radical reform of the CAP since its creation. Ten years later, another, more moderate CAP reform, the 'Imperfect Storm' (Swinnen, 2015a), took place. Swinnen (2015a) identifies four key domains of this reform: first, the drivers and the assessment of the reform (Swinnen, 2015b); second, the factors influencing policy outcomes, including internal, such as the Multiannual Financial Framework (Matthews, 2015), as well as external factors, such as the WTO negotiations (Swinbank, 2015); third, the content, including direct payments (Sahrbacher, Balmann, and Sahrbacher, 2015) or the so-called greening (Erjavec, Lovec, and Erjavec, 2015); and finally, the institutional aspects, with focus on the role of the European Parliament after the entering into force of the Treaty of Lisbon (Fertő and Kovács, 2015; Olper and Pacca, 2015). The 2013 CAP reform was the first one in which the EP was a colegislator with the Council, which partly explains why the decision-making of the CAP in the European Parliament is mostly unexplored.

Throughout the last CAP reforms and the EU's legislation on agricultural policy, scholars focused on the external and internal stakeholders, their motivations and influence on the policy and legislative outcomes. Similarly, the driving forces, constraints and achievements of reforms have been part of the political and academic discourse. On the other hand, the decision-making of the CAP, the role and influence of various stakeholders on the legislative outcome is still unexplored. This is especially true for the European Parliament and its members.

This article aims at filling this gap by analysing the role of the Members of the European Parliament's Committee on Agriculture and Rural Development (COMAGRI) in the CAP legislation through quantifiable power scores. Contrary to previous studies on intra-EP structures, such as committees or EP Groups (Whitaker, 2005), we concentrate on the decision-making at the level of individual EP members.

In particular, we provide the voting power ranking of the MEPs—both Members and Substitute Members - of COMAGRI based on their policy positions along two dimensions: ideological spectrum of national parties and the local significance of agriculture. Our choice is supported by results that show MEPs voting behaviour influenced by ideology (the MEP's party group affiliation) and also nationality (Cencig and Sabani, 2017). We position members in the ideology space given by these dimensions. For the first, we use the left-right measure $\left(\right.$ ParlGov $\left.^{1}\right)$ of the members' national political parties (Döring and Manow, 2016); for the latter, we use the share of employment in agriculture in the NUTS 2 region of the MEP's place of birth. The Banzhaf index we use calculates the probability that a given voter was instrumental if the committee has made a decision.

1 The ParlGov dataset is a well-established source that contains various kinds of information on all EU and most OECD democracies. The left/right classification of party positions is created by expert surveys. The definition of left/right follows standards established by (Castles and Mair, 1984), (Huber and Inglehart, 1995) and (Kenneth and Michael Laver, 2006). 


\section{Influence on EU decision-making}

There is a broad literature on the role and influence of EP committees. Westlake (1994, p. 191) describes the Standing Committees as the 'legislative backbone' of the European Parliament. Many authors emphasise the increasing role of committees in shaping EU legislation. Besides, Mamadouh and Raunio (2003) find that the allocation of the rapporteurship measures the power of Committee members. ${ }^{2}$ Neuhold (2001) argues that the key players in the EP committees are the committee chairmen, the vice-chairs-holding the formal positions in the committees, as well as the rapporteurs, also draftsmen of opinion, shadow rapporteurs and party coordinators in the committees. Kaeding and Obholzer (2012) also emphasised the crucial role of EP group coordinators in the legislative process at the EP committee level. In line with Benedetto (2005), Marshall (2010) also states that rapporteurs are one of the most powerful actors of the committee but also added that the distribution of influence among ordinary members of the committees is still unclear. Ringe (2009) provides a general description and analysis of EP politics focusing on the individual level.

Regarding the role of COMAGRI in the EP, Greer and Hind (2012) concludes that the COMAGRI plays a key role in agricultural legislation. Ferto and Kovács (2015) corroborated this finding. Pokrivcak, Crombez, and Swinnen (2006) looked at the impact of voting rules and Member States' preferences in COMAGRI in connection to the CAP reforms.

In the following, we introduce our methods: the power index approach and the policy space of the voters, and then present our data and results. We close by a brief discussion of the results.

\section{Methodology}

The Agricultural Committee and its members can easily find themselves in the line of fire of the various interest groups supporting or rejecting genetically modified products and agricultural subsidies-just to mention two of the hottest topics. In a representative democracy, the agency problem naturally arises, and MEPs are prime targets for lobbyists-if they are not already the agents of one of the interest groups. Whom should a non-governmental organisation try to convince to get the greatest effect? Or what is the number of MEPs a lobbyist needs to likely succeed? Our model enables us to answer these and similar questions. Here, we introduce and explain the spatial voting power method we use.

Groups of voters having the majority to make decisions are called winning coalitions; groups that do not are losing. We are interested in the critical voters, who can turn a winning coalition into a losing one by changing their 'yes' votes to 'no'. Voting power is the probability that one is a deal maker. We compare the power of different MEPs and are therefore interested in the conditional 
probability: what is the probability that a particular voter is a deal maker if a deal has been made-another stream of literature focuses on comparing different voting mechanisms and so the (unconditional) probabilities of being able to make a deal. Felsenthal, Machover, and Zwicker (1998) call the first power as a prize- or P-power and the second power as influence- or I-power. For P-power, the voters share a fixed prize, such as the overall benefit from lobbying effort, and the total power always adds up to 1; I-power estimates the probability that the implemented policy follows the sole interest of a particular voter and is often normalised in such a way that a dictator's power is 1 . Ppower models the office-seeking, while I-power the policy seeking behaviour of voters (Felsenthal and Machover, 2004: 11). I-power can compare not only the powers of different players in a voting situation but also how these change across different mechanisms. Since the mechanism does not change in the studied period, for computational convenience, we focus on P-power. Henceforward, we use the expressions 'influence' and 'power' interchangeably as a reference to P-power. P-power is commonly measured by the ShapleyShubik index (Shapley and Shubik, 1969), but, incidentally, for non-weighted voting, the Shapley-Shubik index coincides with the normalised version of the Banzhaf measure: the Banzhaf index (Banzhaf, 1965), which is easier to calculate.

We are not the first to measure the actors' voting power in legislative and political decisions (Felsenthal and Machover, 2004). In the context of EU, most papers deal with the power of Member States in the Council of the European Union (Herne and Nurmi, 1993) — better known by its former name: the Council of Ministers-studying the fairness of voting weights before the Lisbon Treaty (Le Breton, Montero, and Zaporozhets, 2012), and how existing members' powers changed due to the extensions of the Union (Hosli, 1993; Felsenthal and Machover, 1997) or changes in the voting rules (Felsenthal and Machover, 2001; Barr and Passarelli, 2009; Kóczy, 2012). It is important to stress that most of these models study voting power $a$ priori, that is without taking policy positions into account, motivated by the assumption that we do not know the subject of voting and therefore the voters' policy positions in advance. When we study voting in the COMAGRI, this approach is neither informative nor appropriate: members have clear policy positions that we can approximate by their political inclinations and their agricultural affinity. We present a model with this information taken into account.

We model voting situations by simple cooperative games, where power is the payoff. Formally, let $N$ denote the set of voters and $\mathcal{W}$ the set of winning coalitions. We are interested in those members $i$ of winning coalitions $C \in \mathcal{W}$ that can turn the coalition into losing $C \backslash\{i\} \notin \mathcal{W}$ by refusing their support. We call such voters critical. Let $\mathcal{W}_{i}=\{C \subseteq N \mid C \in \mathcal{W}, C \backslash\{i\} \notin$ $\mathcal{W}$ \} denote the set of winning coalitions where voter $i$ is critical and let $\eta_{i}=\left|\mathcal{W}_{i}\right|$ denote the number of such coalitions. Then, the Banzhaf index is 
defined as

$$
\beta_{i}=\frac{\eta_{i}}{\sum_{j \in N} \eta_{j}} .
$$

Calculating the power indices of symmetric voting bodies is not very interesting as the powers are also symmetric. In this case, however, we have two aspects that break the symmetry: we know who the voters are and-to some extent-how they will vote; moreover, there is a substitution mechanism to replace absent members by substitutes - the first we model by spatial voting and the second by a Monte Carlo simulation.

\subsection{Preference space}

The standard version of the Banzhaf index ignores the voters' policy preferences. It practically assumes that cooperation among any group of MEPs is equally likely. This could not be further from reality! It is reasonable to assume that a decision - a CAP policy position - that is acceptable to both a liberal (ALDE) and a conservative (ECR) MEP is acceptable to more central, moderate (S\&D and EPP) MEPs too, as long as they have a comparable interest in agriculture. In the so-called games on convex geometries (Edelman, 1997), it is presumed that only convex coalitions may form. Convexity means that for each dimension of the ideology space, we specify a range (i.e. an interval), and only those members whose positions fall into both ranges may form a coalition. The Banzhaf index has already been extended to games over convex geometries (Bilbao, Jiménez, and López, 1998).

To establish the convex geometry, we treat COMAGRI members as points on the ideology space where the horizontal axis $(x)$ represents the ideological position of the national parties of COMAGRI members, and the vertical axis (y) represents the share of agricultural employment of their NUTS 2 regions. In the two-dimensional ideology space for each convex coalition, we can draw a rectangle containing all members, and no other voters (see Figure 1). For expositional simplicity, we identify coalitions with the smallest of such rectangles: for each side of the rectangle, there is at least one voter located on that side. Note that it may happen that a voter is located at the corner of a rectangle thereby fixing two sides of it. Hence, the boundary of a rectangle can be formed by 2, 3 or 4 voters.

Where are the critical players? A coalition is winning if it has at least the majority of votes.

If one of the voters switches her vote to 'no'-by our convexity assumption, this can only be one of the voters on the boundary of the rectangle - the new coalition becomes losing only if it minimally meets the majority requirement. Therefore, a voter is critical if the coalition is minimal winning, and he is located on the boundary of the corresponding rectangle. We calculate the influence of each COMAGRI member by finding all rectangles corresponding to minimal winning coalitions and checking how frequently a particular MEP is on the boundary of such rectangles. Kóczy and Sziklai (2015) applied a similar 


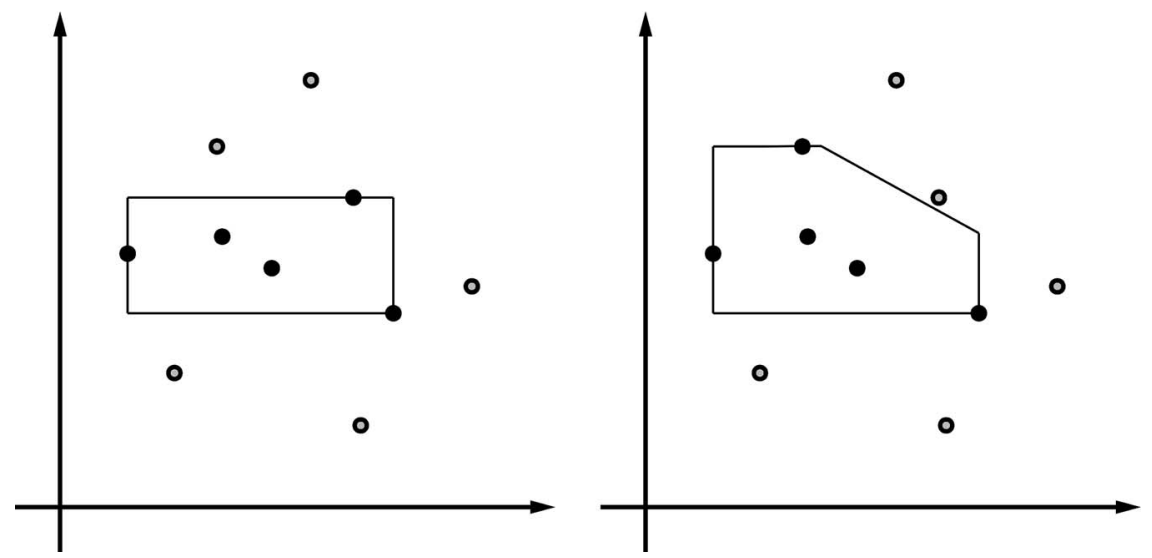

Fig. 1. Convex (on the left) and concave coalitions (on the right). Note that the coalition on the right is convex in the Euclidean sense, but not as a voting group

methodology for the power ranking of the cardinals in the Papal Conclave in 2013.

\subsection{Example}

Let us illustrate the method by the following example. Figure 2 shows a policy space with seven actors labelled with capital letters. We look for convex coalitions with at least four members, but for a player to be critical, the coalition must be losing without the player. In short, we are looking for coalitions with exactly four players. Algorithmically, we fix one node and then iterate through the nodes to set each side of the rectangle.

Let us look at Player A. The coalition ABEF has precisely four players, but it is not convex, as any proposition that both $\mathrm{A}$ and $\mathrm{E}$ and both $\mathrm{B}$ and $\mathrm{F}$ find acceptable is also acceptable for $\mathrm{C}$. We argue that the coalition is actually $\mathrm{ABCFE}$ - and in this coalition, $\mathrm{A}$ is no longer critical.

Now let us find all four-player coalitions containing A. The algorithm explained by Kóczy and Sziklai (2015) is a little more formal, but the main idea is to try to find rectangles by adjusting the sides. We first take the most Southern point, B, and the most Eastern point, D, and then try to find a matching on the Northern side for the rectangle so that (i) A is contained in it; (ii) it is convex and (iii) it has exactly four members. Fortunately, ABCD is such a rectangle. There are no other options, so we take the next most Eastern point, E. Again, $\mathrm{ABCE}$ is a suitable rectangle. The next most Eastern point is $\mathrm{B}$, but this time, we must go as high up North as $\mathrm{F}$ to get ABCF. The next most Eastern point is $\mathrm{F}$, but if $\mathrm{F}$ is on the Eastern side of the rectangle, then $\mathrm{B}$ is not included, so this may not work; therefore, all the options are exhausted with B. The next most Southern point is $\mathrm{C}$; here, we find rectangles ACDE, ACEF and ACFG. 


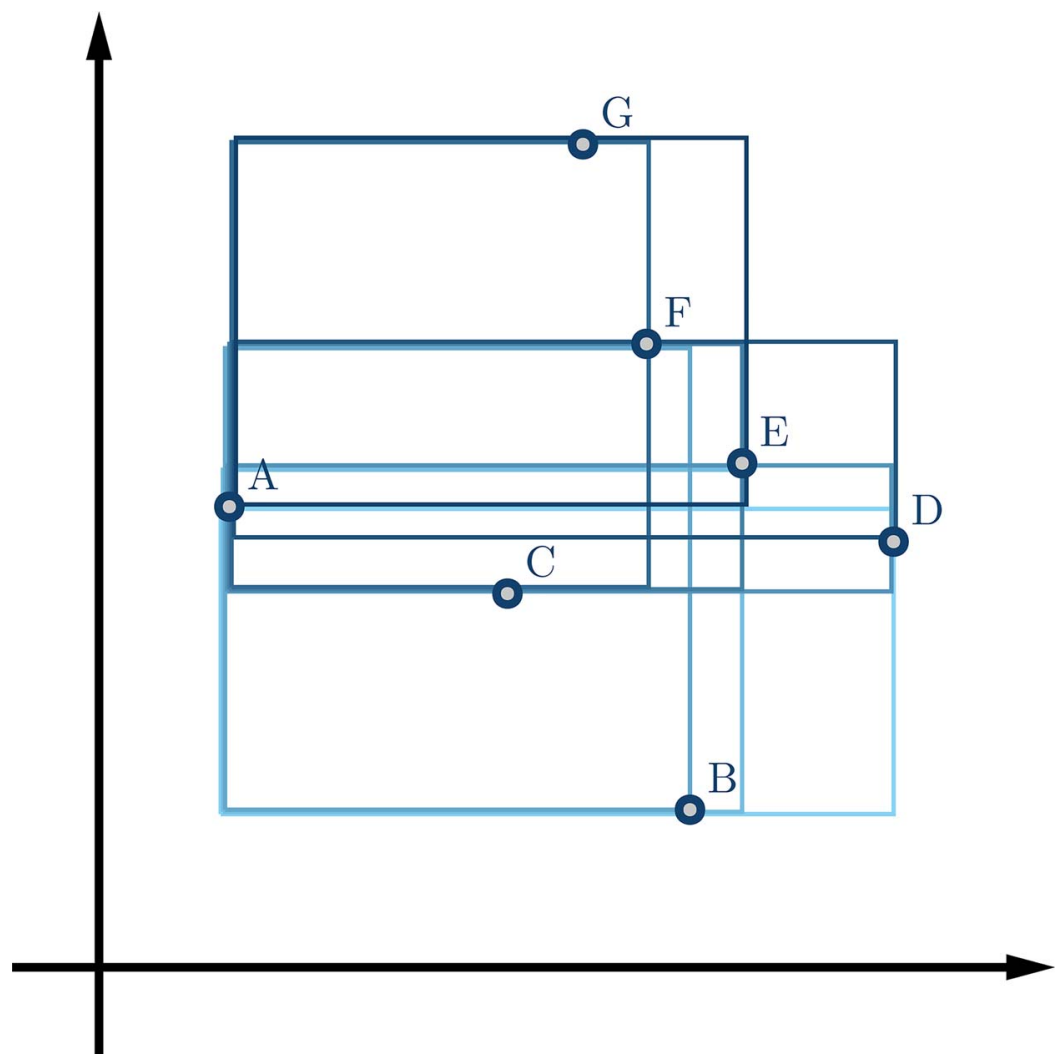

Fig. 2. Convex minimal winning coalitions through voter A. For sake of clarity the rectangles are slightly shifted

For D, we only have ADEF; at last for A, AEFG. A is not critical in any other rectangle.

When all the options with $\mathrm{A}$ are exhausted, one must look at the next most Western point $\mathrm{C}$ and start generating further rectangles: $\mathrm{BCDE}, \mathrm{BCEF}, \mathrm{BCFG}$, CDEF and CEFG. Next comes G with BEFG and DEFG. Finally, F with BDEF. With this we have generated all the rectangles, now we only need to check which members correspond to internal and which to borderline points. Eventually, we get 8, 8, 8, 7, 8, 7 and 6 instances when A-G are critical; consequently, the Banzhaf indices are $0.153,0.153,0.153,0.134,0.153,0.134$ and 0.115 .

\subsection{Replacements}

In the committees of the EP, a system of substitution ensures sufficient participation. When a member is absent, a substitute replaces her. At such a time, the member does not participate in the voting and therefore cannot be 
critical either. Instead, the substitute votes and as a voter, he may also be critical for certain issues. We must, therefore, consider substitutions and substitutes.

Each committee has a pre-selected list of substitutes. There is no official priority ranking among substitutes; there are no first, second, etc. substitutes; the mechanism to invite substitutes is not regulated and is not transparent. Past participation data, if available, may help us to estimate a member's or a substitute's availability: his or her probability of participation in voting; otherwise, we must work with uniform probabilities. Irrespective of the probabilities used, we must consider every possible constellation, that is every possible instance of the Committee where absent members are replaced by substitutes. Considering that a voting session consists of 46 representatives in the 20142019 EP term where some members are replaced with substitute members, the number of different possible configurations is astronomical. Thus, we estimate the Banzhaf indices by using a Monte Carlo method.

\subsection{Monte Carlo simulation}

Since the number of possible member-substitute constellations is very high (over $4 \times 10^{26}$ for a 46 -member Committee), an exact calculation is not feasible, so we estimate the Banzhaf indices by using a Monte Carlo method that we explain in the following.

Based on the roll-call votes of the first half of the 2014-2019 EP Term, we derive participation rates for each Member and Substitute. Given the observed probabilities on the Members' and Substitutes' participation, we randomly generate an instance of the Committee: first, we determine for each member if he or she is present, using the probability of presence. Substitutes are selected proportionally to their probability of presence.

Since some of the members are substituted, different winning coalitions can form. For such an instance, we can efficiently calculate the Banzhaf index. We take the average of these indices for 100,000 such simulations as an estimate of the expected Banzhaf index (see Appendix A). The method is not entirely new; Matsui and Matsui (2000) have already applied it for weighted majority games, but we are the first to use it for voting games over convex geometries. In the following, we explain how we create the preference space. Note that generalised weighted voting games (Kóczy and Pintér, 2011) are also defined using an expected value over different voting scenarios, but with a fixed probability of absence, the model can be studied analytically.

In the eight EP term between 2014 and 2019, the COMAGRI had 46 Members and the same number of Substitute Members. The ideological and national distribution of Members and Substitutes in EP Committees reflect the weight of EP Groups and the Member States in the Parliament. It is important to note that substitution in EP committees is not on a Member-to-Substitutes relationship, but any Substitute Member can replace any missing (standing) Member. In the power ranking of COMAGRI Members and Substitutes, we finally ranked 71 members: the number of MEPs who participated in the 15 COMAGRI roll-call votes in the first half of this EP-term. 


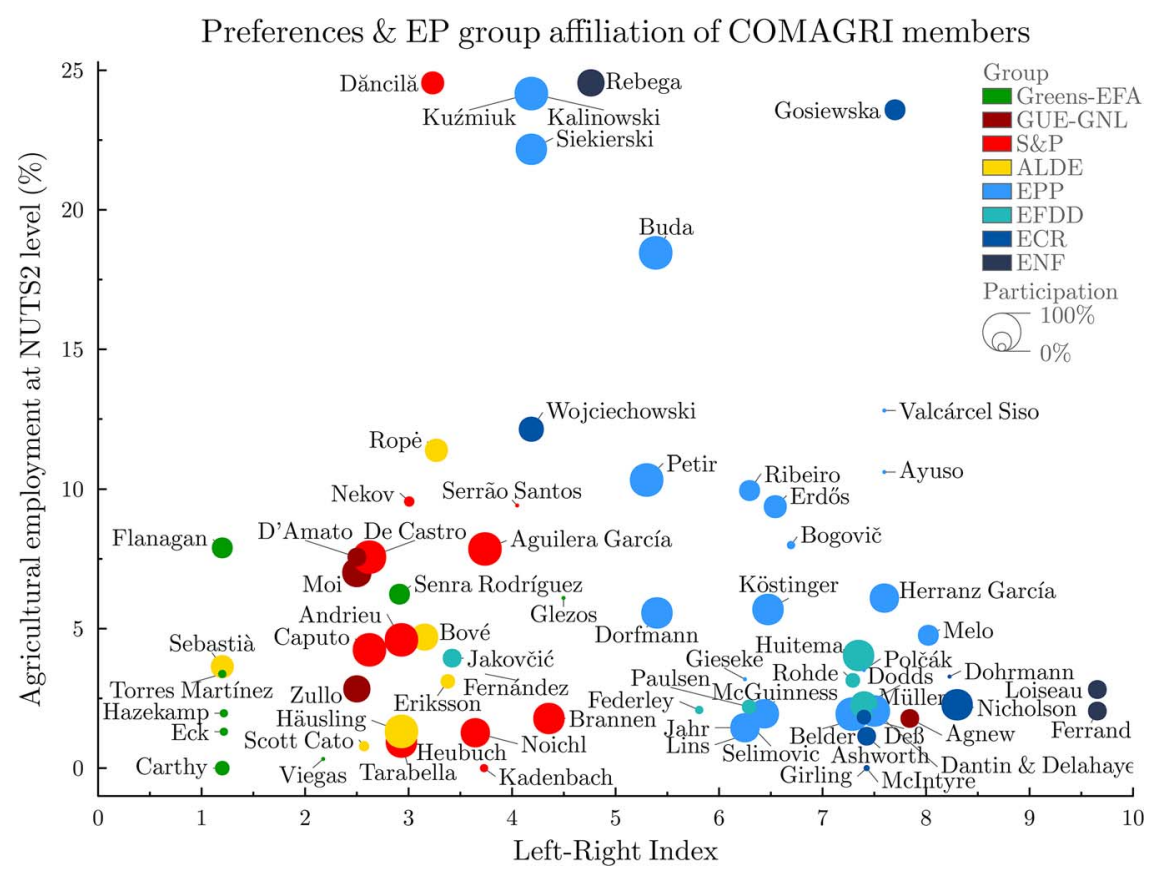

Fig. 3. The political group affiliation, policy position and participation rate of COMAGRI members

\section{Data}

The dataset of this analysis contains three sources of information. The first source of the dataset is the ideological position of the MEPs based on the left-right ideological orientation of their national parties (Döring and Manow, 2016). The second pillar of the dataset is the percentage of agricultural employment (Eurostat, 2015) in the NUTS2 region of the MEP. These two constitute the two dimensions of the ideology space. The third source of information is the participation rates of the members derived from roll-call votes of heterogeneous legislative proposals and amendments in the COMAGRI during the first 2 years of the eight EP-term (see Figure 3).

\section{Results}

At first glance, the results, presented in detail in Appendix A and depicted in Figure 4, are in line with our intuition. Members with low absence rates are generally ranked higher than members with high absence rates. Similarly, high substitution probability comes with better ranking. The interesting cases are the exemptions. How come that some members with relatively high absence value, like Rosa D'Amato ${ }^{3}$ (47 per cent) and Jordi Sebastiá (33 per cent), are

3 Note that D'Amato is a Substitute, which explains her "high" absence. It is more surprising that she is present in 53 per cent of the votes. 


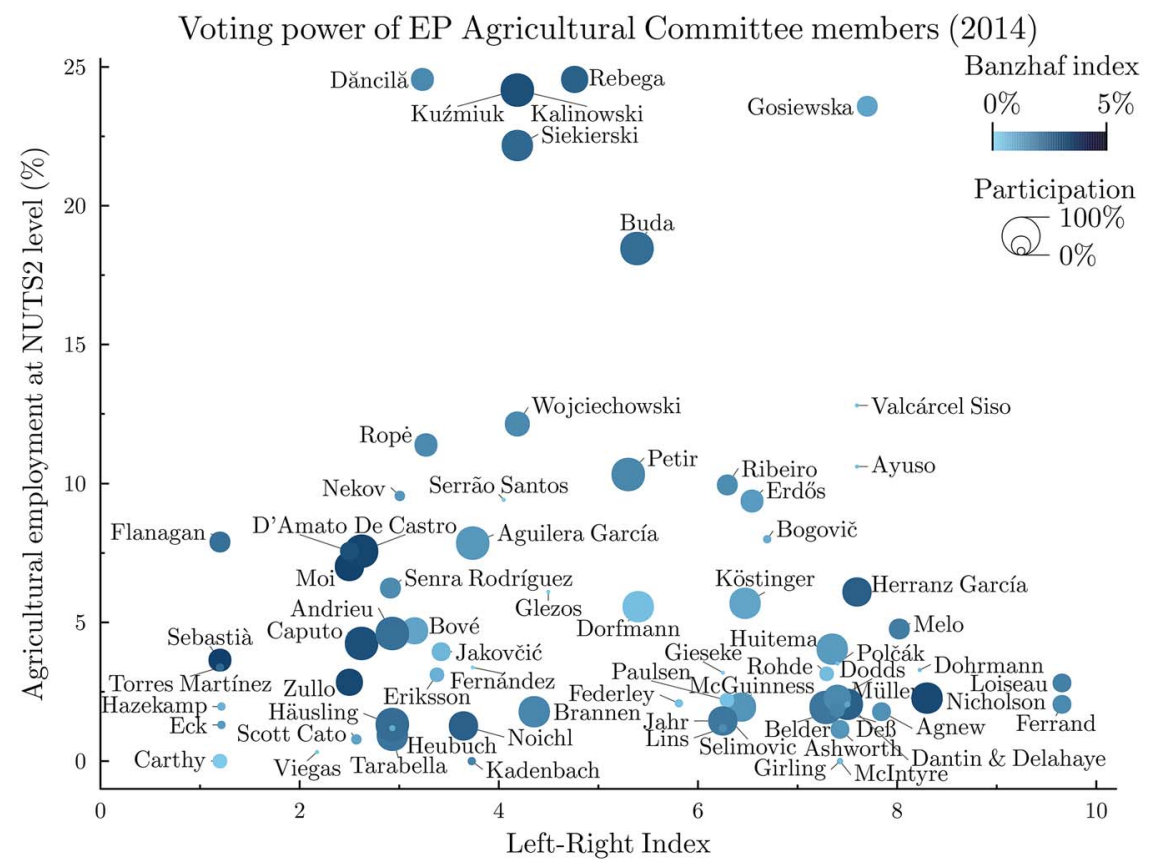

Fig. 4. Voting power of the EP Agricultural Committee members (2014)

influential while a member like Dorfmann (7 per cent) who is almost always present is virtually powerless? The answer comes from the spatial position of these players. Kóczy and Sziklai (2015) observed that players close to the centre of the ideology space are rarely critical, while those with relatively extreme positions in one dimension and moderate positions in the other one are likely to do well and become an influential member. Our results (see Figure 3) corroborate this finding. COMAGRI members with either extreme ideological or extreme agricultural positions ${ }^{4}$ are the most influential ones. In particular, 8 out of the top 10 MEPs in our ranking-Sebastiá, Moi, De Castro, Zullo, Caputo, Kuzmiuk, D'Amato and Herranz García—are all located in such policy positions.

\subsection{Formal positions}

Previous research reveals the importance of 'strong' persons in EU politics and decision-making. Now, we provide an overview of this fact for the European

4 "Extreme agricultural position" refers to the fact that according to our measure the member in question is positioned on the extremes, meaning that he or she was born in a NUTS 2 region with either a very high or very low share of agricultural employment and thus is presumed to have either a very high or very low agricultural affinity. It does not mean that the member is a fundamentalist. 
Parliament's agri-committee. First, we look at the formal Committee positions, the chair and the vice-chairs. We see in Appendix A that in the power ranking, Chair Siekierski takes the 14th position (among the 71 members). He is the most powerful member of those with formal positions.

Three out of four vice-chairs, Eric Andrieu (19th/71), Viorica Dăncilă (30th/71) and Janusz Wojciechowski (33th/71), are ranked above average, while Clara Eugenia Aguilera García (41th/71) is ranked slightly below. The average rank of members with formal positions is 27.4 , which is considerably higher than 36-the average rank for the whole Committee. In this sense, our empirical findings are in line with Neuhold (2001).

There are three differences that we should note. Firstly, Neuhold (2001) identified key players by analysing interviews and reviewing legislative files, which is a notably different approach than what we follow in this paper. Secondly, here, the relative importance of members with formal positions comes mostly from their conscientiousness - they are almost always present (have 13.3 per cent absence rate versus 24.8 per cent for the rest). In comparison, their average rank without substitutions is slightly below group average (28.2 versus 23.5). Finally, with the exception of Eric Andrieu, all members with formal positions have distinctively high agricultural affinity. Given the purpose of the Committee, this bias is hardly surprising (Figure 4).

\subsection{Rapporteurships}

We also look at the rapporteurships in the legislative files we analysed. We see that only two MEPs-De Castro and Nicholson-have more than one legislative proposal. Our calculations show that the ranking of rapporteursbold in Appendix A-concentrate on the top of the list. In particular, De Castro takes the 3rd position, and 7 out of 12 rapporteurs, Nicholson (5th), Dantin (10th), Sikierski (14th), Hausling (16th), Tarabella (20th) and Melo (23th, all out of 71) are in the first half of the ranking. The average rank of rapporteurs (26.45) is again significantly higher than the average rank of the whole group (36). We conclude that members with high voting power tend to become rapporteurs. These results seem to confirm the findings of earlier research revealing the importance of rapporteurs in the EP committees (Benedetto, 2005; Ringe, 2009; Marshall, 2010). Again, let us emphasize the differences between our and the existing methodologies. Benedetto (2005) draw his conclusions based on case studies, while Ringe (2009) and Marshall (2010) rely mostly on interviews with stakeholders and partly on the quantitative analysis of legislative votes.

\subsection{Party coordinators}

Party coordinators of EP Groups in the Committees - underlined in Appendix A-play a vital role in the legislative process (Neuhold, 2001; Kaeding and Obholzer, 2012). Our analysis reinforces this view as five out of seven EP Group coordinators are in the first half of the ranking with an average rank 
Table 1. The participation of the different EU member states in the COMAGRI also compared to their power in the Council of the European Union (Kóczy, 2012)

\begin{tabular}{|c|c|c|c|c|c|c|c|c|}
\hline Country & \#MEPs & $\begin{array}{c}\text { Share of } \\
\text { MEPs }\end{array}$ & $\begin{array}{l}\text { Avg. part. } \\
\text { rate }\end{array}$ & $\begin{array}{l}\text { Weighted } \\
\text { share of } \\
\text { members }\end{array}$ & $\begin{array}{c}\text { Share of } \\
\text { (weighted) } \\
\text { subs }\end{array}$ & $\begin{array}{c}\text { Share of } \\
\text { weighted } \\
\text { MEPs }\end{array}$ & $\begin{array}{l}\text { Share of } \\
\text { total power }\end{array}$ & $\begin{array}{l}\text { Share of } \\
\text { power in } \\
\text { the Council } \\
\text { of the EU }\end{array}$ \\
\hline Italy & 5 & $10.87 \%$ & $92 \%$ & $13.10 \%$ & $10.15 \%$ & $12.72 \%$ & $14.51 \%$ & $10.24 \%$ \\
\hline Germany & 5 & $10.87 \%$ & $91 \%$ & $12.93 \%$ & $11.49 \%$ & $12.74 \%$ & $13.19 \%$ & $14.43 \%$ \\
\hline Spain & 4 & $8.70 \%$ & $79 \%$ & $8.94 \%$ & $6.51 \%$ & $8.63 \%$ & $11.10 \%$ & $7.56 \%$ \\
\hline UK & 5 & $10.87 \%$ & $70 \%$ & $10.02 \%$ & $9.00 \%$ & $9.89 \%$ & $10.28 \%$ & $10.95 \%$ \\
\hline Poland & 5 & $10.87 \%$ & $83 \%$ & $11.76 \%$ & $0.00 \%$ & $10.24 \%$ & $9.68 \%$ & $6.43 \%$ \\
\hline France & 5 & $10.87 \%$ & $76 \%$ & $10.79 \%$ & $2.49 \%$ & $9.72 \%$ & $9.50 \%$ & $11.27 \%$ \\
\hline Romania & 3 & $6.52 \%$ & $82 \%$ & $7.03 \%$ & $0.00 \%$ & $6.12 \%$ & $5.92 \%$ & $3.74 \%$ \\
\hline Portugal & 1 & $2.17 \%$ & $60 \%$ & $1.71 \%$ & $14.18 \%$ & $3.32 \%$ & $3.74 \%$ & $2.28 \%$ \\
\hline Ireland & 3 & $6.52 \%$ & $62 \%$ & $5.32 \%$ & $0.00 \%$ & $4.64 \%$ & $3.51 \%$ & $1.44 \%$ \\
\hline Netherlands & 2 & $4.35 \%$ & $57 \%$ & $3.22 \%$ & $7.66 \%$ & $3.79 \%$ & $3.46 \%$ & $3.27 \%$ \\
\hline Austria & 1 & $2.17 \%$ & $93 \%$ & $2.65 \%$ & $3.83 \%$ & $2.80 \%$ & $2.60 \%$ & $2.02 \%$ \\
\hline Croatia & 1 & $2.17 \%$ & $100 \%$ & $2.85 \%$ & $10.15 \%$ & $3.79 \%$ & $2.15 \%$ & $1.39 \%$ \\
\hline Sweden & 2 & $4.35 \%$ & $37 \%$ & $2.08 \%$ & $11.49 \%$ & $3.30 \%$ & $2.12 \%$ & $2.18 \%$ \\
\hline Belgium & 1 & $2.17 \%$ & $93 \%$ & $2.65 \%$ & $0.00 \%$ & $2.31 \%$ & $1.94 \%$ & $2.42 \%$ \\
\hline Lithuania & 1 & $2.17 \%$ & $67 \%$ & $1.91 \%$ & $0.00 \%$ & $1.66 \%$ & $1.50 \%$ & $1.20 \%$ \\
\hline Bulgaria & 0 & $0.00 \%$ & $0 \%$ & $0.00 \%$ & $5.17 \%$ & $0.67 \%$ & $1.28 \%$ & $1.82 \%$ \\
\hline Hungary & 1 & $2.17 \%$ & $67 \%$ & $1.91 \%$ & $0.00 \%$ & $1.66 \%$ & $1.13 \%$ & $2.21 \%$ \\
\hline Denmark & 1 & $2.17 \%$ & $40 \%$ & $1.14 \%$ & $1.34 \%$ & $1.17 \%$ & $1.05 \%$ & $1.59 \%$ \\
\hline Slovenia & 0 & $0.00 \%$ & $0 \%$ & $0.00 \%$ & $3.83 \%$ & $0.50 \%$ & $0.82 \%$ & $1.09 \%$ \\
\hline Czech Republic & 0 & $0.00 \%$ & $0 \%$ & $0.00 \%$ & $1.34 \%$ & $0.17 \%$ & $0.38 \%$ & $2.30 \%$ \\
\hline Greece & 0 & $0.00 \%$ & $0 \%$ & $0.00 \%$ & $1.34 \%$ & $0.17 \%$ & $0.12 \%$ & $2.37 \%$ \\
\hline Finland & 0 & $0.00 \%$ & $0 \%$ & $0.00 \%$ & $0.00 \%$ & $0.00 \%$ & $0.00 \%$ & $1.57 \%$ \\
\hline Slovakia & 0 & $0.00 \%$ & $0 \%$ & $0.00 \%$ & $0.00 \%$ & $0.00 \%$ & $0.00 \%$ & $1.56 \%$ \\
\hline Latvia & 0 & $0.00 \%$ & $0 \%$ & $0.00 \%$ & $0.00 \%$ & $0.00 \%$ & $0.00 \%$ & $1.08 \%$ \\
\hline Estonia & 0 & $0.00 \%$ & $0 \%$ & $0.00 \%$ & $0.00 \%$ & $0.00 \%$ & $0.00 \%$ & $0.98 \%$ \\
\hline Cyprus & 0 & $0.00 \%$ & $0 \%$ & $0.00 \%$ & $0.00 \%$ & $0.00 \%$ & $0.00 \%$ & $0.92 \%$ \\
\hline Luxembourg & 0 & $0.00 \%$ & $0 \%$ & $0.00 \%$ & $0.00 \%$ & $0.00 \%$ & $0.00 \%$ & $0.88 \%$ \\
\hline Malta & 0 & $0.00 \%$ & $0 \%$ & $0.00 \%$ & $0.00 \%$ & $0.00 \%$ & $0.00 \%$ & $0.85 \%$ \\
\hline
\end{tabular}

of 26.14. Four of them ranked in the top 25, including the coordinators of the two main EP Groups, EPP (21st) and S\&D (3rd).

\subsection{Nationality}

Cencig and Sabani (2017) argue that the members' nationalities may play a role in their voting behaviour. In Table 1, we present a detailed overview of participation for the different Member States. The first two columns show how many of the 46 representatives a country delegates to the Committee, both in absolute and in percentage terms, followed by their average participation rates in the 15 roll-call votes. With an average participation of about 76 per cent, those countries with higher attendance effectively increase their representation (Column 4) making Italy the most significant player taking 5 out of the top 10 positions. Column 5 shows the choice of substitutes by nationality weighted by the participation probabilities. 
Column 6 shows the overall participation by country, resulting in an aggregated power index (Column 7) ${ }^{5}$. It is quite remarkable how a high participation rate for members and a high probability of substitution from a given country can increase overall presence and with a fortunate location in the ideology space all these translate into a high total power for Italy, Poland, Portugal, Romania and Spain-especially in comparison with the power share in the Council of the European Union that is often seen as the overall benchmark of a country's power in the EU (Column 8). Where there are winners, there are also losers, including Germany, Sweden, France or the countries not represented at all in COMAGRI.

\subsection{Political groups}

A similar analysis of the different political groups of the EP reveals thehardly surprising - dominance of the European People's Party (EPP) and the Progressive Alliance of Socialists and Democrats (S\&D) (Table 2). It is a little more surprising that the high power is to a large extent due to a high level of discipline: a high, nearly 90 per cent participation rate of members.

Table 2. The participation and power of the different political groups of the EP. The share of EP seats is calculated for MEPs belonging to one of the groups only

\begin{tabular}{|c|c|c|c|c|c|c|c|c|}
\hline Country & \#MEPs & $\begin{array}{l}\text { Share of } \\
\text { MEPs }\end{array}$ & $\begin{array}{l}\text { Avg. part. } \\
\text { rate }\end{array}$ & $\begin{array}{l}\text { Weighted } \\
\text { share of } \\
\text { members }\end{array}$ & $\begin{array}{c}\text { Share of } \\
\text { (weighted) } \\
\text { subs }\end{array}$ & $\begin{array}{c}\text { Share of } \\
\text { weighted } \\
\text { MEPs }\end{array}$ & $\begin{array}{c}\text { Share of } \\
\text { total power }\end{array}$ & $\begin{array}{c}\% \text { of } \\
\text { EP seats }\end{array}$ \\
\hline EPP & 13 & $28.26 \%$ & $88 \%$ & $32.66 \%$ & $27.01 \%$ & $31.93 \%$ & $28.10 \%$ & $29.60 \%$ \\
\hline S\&D & 9 & $19.57 \%$ & $89 \%$ & $22.78 \%$ & $10.34 \%$ & $21.17 \%$ & $20.58 \%$ & $25.78 \%$ \\
\hline ECR & 5 & $10.87 \%$ & $76 \%$ & $10.79 \%$ & $12.84 \%$ & $11.06 \%$ & $12.58 \%$ & $10.10 \%$ \\
\hline Greens-EFA & 4 & $8.70 \%$ & $79 \%$ & $8.94 \%$ & $15.33 \%$ & $9.77 \%$ & $10.10 \%$ & $6.96 \%$ \\
\hline EFD & 3 & $6.52 \%$ & $73 \%$ & $6.26 \%$ & $10.15 \%$ & $6.77 \%$ & $9.84 \%$ & $6.14 \%$ \\
\hline GUE-NGL & 4 & $8.70 \%$ & $45 \%$ & $5.13 \%$ & $10.34 \%$ & $5.80 \%$ & $8.11 \%$ & $7.09 \%$ \\
\hline ENF & 3 & $6.52 \%$ & $62 \%$ & $5.30 \%$ & $0.00 \%$ & $4.61 \%$ & $5.54 \%$ & $5.05 \%$ \\
\hline ALDE & 5 & $10.87 \%$ & $57 \%$ & $8.14 \%$ & $13.98 \%$ & $8.90 \%$ & $5.16 \%$ & $9.28 \%$ \\
\hline
\end{tabular}

There is another reason why participation is important: S\&D substitutes are rarely invited. Looking at smaller parties, we find that participation rates are lower, as low as 45 per cent for European United Left-Nordic Green Left (GUE-NGL) by which the representatives effectively halve their influence.

Europe of Freedom and Direct Democracy shows a very strong performance for one of the smallest political groups: despite having only three members in COMAGRI, the group has nearly 11 per cent aggregated influence. Finally, we also note the weak performance of the Alliance of Liberals and Democrats for Europe (ALDE) and the Europe of Nations and Freedom (ENF) due to low participation rates.

5 As an important technical note we must stress that the aggregating the power of a state's individual representatives is not the same as voting en bloc. We therefore do not assume coordinated voting at the country level. 

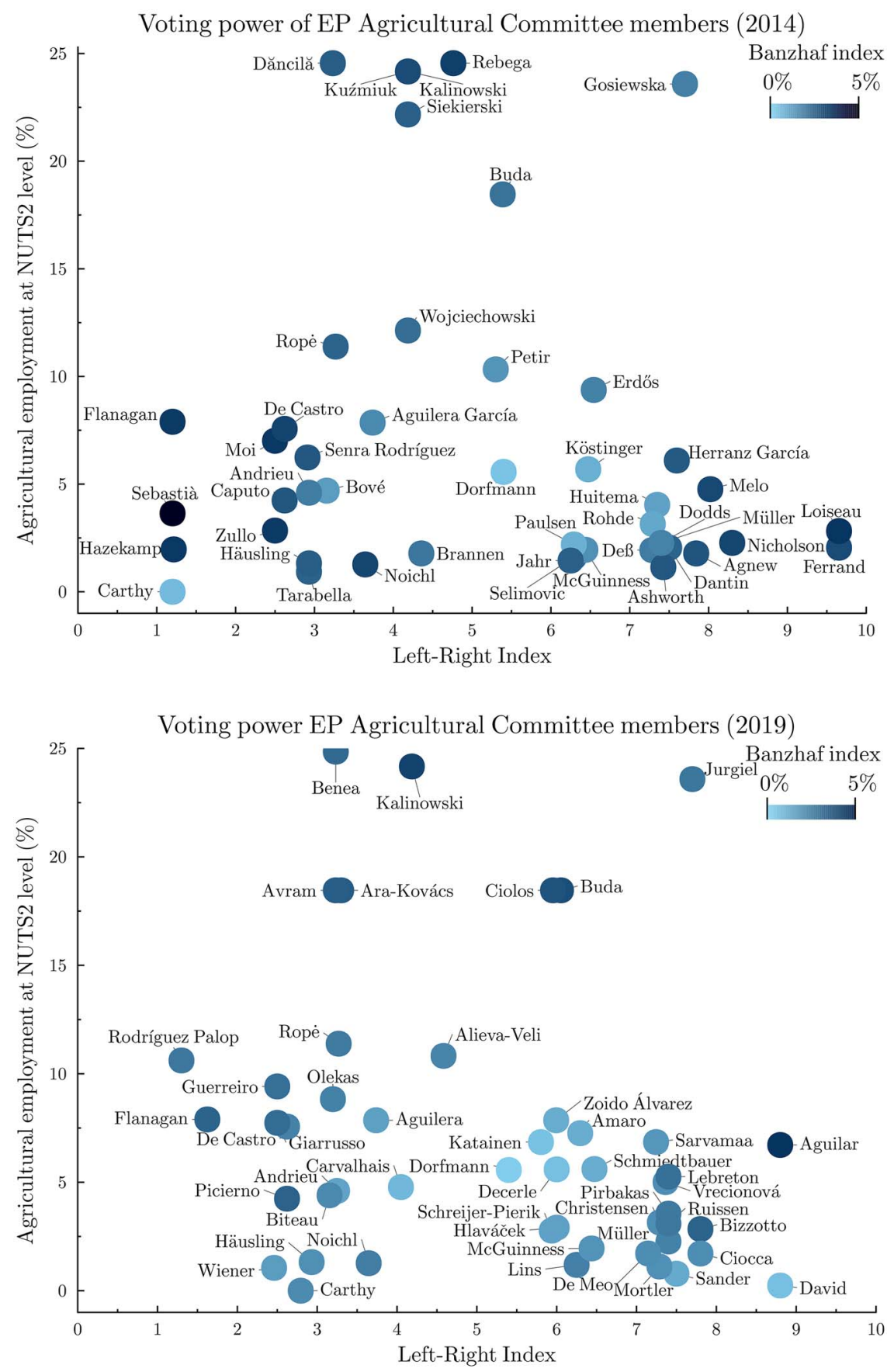

Fig. 5. Voting powers of COMAGRI members in the 2014-19 and 2019-24 periods without substitutions. In order to have an undistorted picture, Benea's agricultural affinity (45.8 per cent) was lowered 


\section{Outlook for 2019-2024}

Beyond the theoretical interest for the last parliamentary period, our method enables us to make predictions for the new, 2019-2024 period-with some limitations. We base our calculations on three sources of data. As soon as the new members and substitutes of COMAGRI are known, their party positions together with their region of origin determine their locations in the policy space. With these data, we can calculate the members' powers, thus ignoring substitutes (see Figure 5). Such a calculation is relevant for major decisions, where members try to be present if at all possible.

This analysis ignores the frequent substitutions; hence, our estimations are only theoretical. With the help of presence data, we can perform a more in-depth analysis. Given our data of the earlier period, we know the average absence rate of members. This way, we can bring in substitutes into our calculations, but this model does not allow to further differentiate among members. As the statistics of the new Committee start to come in, we can update these calculations with individual-level participation data. There are apparent differences among members in their presence rates as well as among substitutes in their substitution rates. Party affiliation, nationality, agricultural affinity or other factors may explain these.

Although formulating any hypothesis on how the Committee will actually vote for a particular proposal is futile as it depends on many factors, it is still worth to examine the ideological positions of the most influential members. The 12 most powerful members' positions (the upper quartile) seem politically balanced along the classical left-right division. Two of them lean to the right side of the ideological spectrum belonging to the first quartile (Q1) in the ranking by the ParlGov index, while four to the left (Q4) - the remaining six falls into the middle (Q2-Q3). The average position (4.31) leans to the left compared with the average (5.23) and the median (5.94). Agricultural affinity, however, paints a remarkably different picture. A total of 7 out of the 12 members can be described as having a very high agricultural affinity (Q1), while the other five fall in the middle (Q2-Q3), no member in the top 12 belong to the bottom quartile. Even their average (15 per cent) would fall in the highest quartile ( 8 per cent + ). The nationality of the most influential members are also interesting. There are four Romanians, four Italians and one from Hungary, Poland, Spain and Ireland each — the Eastern and Southern block is remarkably overrepresented. It would be interesting to see, how these nations, especially Romania and Italy, fare in the legislative negotiations during the ninth EP term in the Committee.

\section{Discussion and conclusions}

The article analyses the voting power of the Members of the Committee on Agriculture and Rural Development of the European Parliament using the Banzhaf index on a spatial voting game. This approach is novel as it goes beyond the allocation of committee seats and shows that policy positions 
may have a substantial impact on one's influence in Committee decisions. We have taken the political left-right position and the home region's agricultural employment level as the two indicators. The first is a traditional choice in describing political positions, the latter was recommended by one of the referees. We do not claim that these would directly determine how an MEP would vote on agricultural matters, but the overall picture we get is fairly robust to the choice of agricultural indicators—even at the individual members' level, the differences are rarely dramatic.

Our main findings are the following. We confirmed the conclusions of Neuhold (2001) that members with formal positions-i.e. the chair vicechairs-have a relatively high power in the analysed EP Committee, although part of the power comes from the fact that these members are very disciplined in attending the voting sessions. Second, following previous research (Benedetto, 2005; Marshall, 2010), we also confirm high power indices for the rapporteurs of the analysed legislative files. Third, the party coordinators, who are the key members of EP Groups at the committee level and have a big say in formulating the legislative proposals (Kaeding and Obholzer, 2012) are also highly ranked, which again correlates with the main findings of previous empirical investigations. Fourth, our results show that the most powerful Member States (Germany, France, Italy and UK) along with countries of high agricultural importance (Spain, Poland, Romania) delegate the most powerful politicians. However, the distribution of power is uneven. Out of the 10 most powerful committee members, five are Italians, two are Spanish, while France, Poland and UK have one members each; interestingly French and German representatives are less influential. This is the reason why Italy displays 50 per cent more power than that of France despite having the same number of Committee members. Future research can be extended to the calculation of power indices based on plenary roll-call votes. The comparison of the two intraEP decision-making stage, committee and plenary, may reveal the power gains or losses of COMAGRI members in the legislative process.

A suitable "profiling" of new members could give more reliable estimates of individual presence data and a better estimate of power in the Committee.

Finally, in Appendix B, we list the members and substitutes that are present in both terms. If we disregard absence, the differences of the Banzhaf-values represent how the members' potential power change from one term to another. Due to the different configuration of the members' positions in the ideology space, some members gain (e.g. Carthy, Kalinowski or Buda) some members lose (e.g. De Castro) influence. When absence data become available, one can conduct a more precise analysis.

\section{Acknowledgements}

Balázs R. Sziklai acknowledges the support of the Hungarian National Research, Development and Innovation Office, grant number K124550. László Á. Kóczy acknowledges the support of the National Research, Development and Innovations Office under grant number K128573. 


\section{References}

Banzhaf, J. F. (1965). Weighted voting doesn't work: a mathematical analysis. Rutgers Law Review 19: 317-343.

Barr, J. and Passarelli, F. (2009). Who has the power in the EU? Mathematical Social Sciences 57: 339-366.

Benedetto, G. (2005). Rapporteurs as legislative entrepreneurs: the dynamics of the codecision procedure in Europe's parliament. Journal of European Public Policy 12: 67-88.

Bilbao, J. M., Jiménez, A. and López, J. J. (1998). The Banzhaf power index on convex geometries. Mathematical Social Sciences 36: 157-174.

Castles, F. and Mair, P. (1984). Left-right political scales: some 'expert' judgements. European Journal of Political Research 12: 73-88.

Cencig, E. and Sabani, L. (2017). Voting behaviour in the European Parliament and economic governance reform: does nationality matter? Open Economies Review 28: 967-987.

Döring, H. and Manow, P. (2016). Parliaments and Governments Database (ParlGov).

Edelman, P. H. (1997). A note on voting. Mathematical Social Sciences 34: 37-50.

Erjavec, E., Lovec, M. and Erjavec, K. (2015). From 'greening' to 'greenwash': the drivers and discourses of CAP 2020 reform. In J. F. M. Swinnen (ed), The Political Economy of the 2014-2020 Common Agricultural Policy: An Imperfect Storm. Brussels: Centre for European Policy Studies, 215-244.

Eurostat. (2015). Employment by Age, Economic Activity and NUTS 2 Regions.

Felsenthal, D. S. and Machover, M. (1997). The weighted voting rule in the EU's Council of Ministers, 1958-1995: intentions and outcomes. Electoral Studies 16: 33-47.

Felsenthal, D. S. and Machover, M. (2001). The treaty of nice and qualified majority voting. Social Choice and Welfare 18: 431-464.

Felsenthal, D. S. and Machover, M. (2004). A priori voting power: what is it all about? Political Studies Review 2: 1-23.

Felsenthal, D. S., Machover, M. and Zwicker, W. (1998). The bicameral postulates and indices of a priori voting power. Theory and Decision 44: 83-116.

Fertő, I. and Kovács, A. (2015). Parliamentary amendments to the legislative proposals of the 2013 CAP reform. In J. F. M. Swinnen (ed), The Political Economy of the 20142020 Common Agricultural Policy: An Imperfect Storm2. Brussels: Centre for European Policy Studies, 379-412.

Greer, A. and Hind, T. (2012). Inter-institutional decision-making: the case of the common agricultural policy. Policy and Society 31: 331-341.

Herne, K. and Nurmi, H. (1993). The distribution of a priori voting power in the EC Council of ministers and the European Parliament. Scandinavian Political Studies 16: 269-284.

Hosli, M. O. (1993). Admission of European free trade association states to the European Community: effects on voting power in the European Community Council of Ministers. International Organization 47: 629-643.

Huber, J. and Inglehart, R. (1995). Expert interpretations of party space and party locations in 42 societies. Party Politics 1: 73-111.

Kaeding, M. and Obholzer, L. (2012). Pulling the strings: party group coordinators in the European Parliament. EIPAScope 1: 13-18.

Kenneth, B. and Michael Laver, M. (2006). Party Policy in Modern Democracies. London: Routledge.

Kóczy, L. Á. (2012). Beyond Lisbon: demographic trends and voting power in the European Union Council of ministers. Mathematical Social Sciences 63: 152-158. 
Kóczy, L. Á. and Pintér, M. (2011). The men who weren't even there: Legislative voting with absentees (MT-DP no. 2011/29). Budapest.

Kóczy, L. Á. and Sziklai, B. (2015). Electing the pope. Homo Oeconomicus 32: 101-116.

Le Breton, M., Montero, M. and Zaporozhets, V. (2012). Voting power in the EU Council of ministers and fair decision making in distributive politics. Mathematical Social Sciences 63: 159-173.

Mamadouh, V. and Raunio, T. (2003). The committee system: powers, appointments and report allocation. Journal of Common Market Studies 41: 333-351.

Marshall, D. (2010). Who to lobby and when: institutional determinants of interest group strategies in European Parliament committees. European Union Politics 11: 553-575.

Matsui, T. and Matsui, Y. (2000). A survey of algorithms for calculating power indices of weighted majority games. Journal of the Operations Research Society of Japan 43: 71-86.

Matthews, A. (2015). The multi-annual financial framework and the 2013 CAP Reform. In J. F. M. Swinnen (ed), The Political Economy of the 2014-2020 Common Agricultural Policy: An Imperfect Storm. Brussels: Centre for European Policy Studies, 169-192.

Neuhold, C. (2001). The legislative backbone keeping the institution upright? The role of European Parliament committees in the EU policy-making process. European Integration Online Papers 5.

Olper, A. and Pacca, L. (2015). The European Parliament's position on market regulation and the impact of the economic context. In J. F. M. Swinnen (ed), The political economy of the 2014-2020 Common Agricultural Policy: An imperfect storm. Brussels: Centre for European Policy Studies, 357-378.

Pokrivcak, J., Crombez, C. and Swinnen, J. F. M. (2006). The status quo bias and reform of the common agricultural policy: impact of voting rules, the European Commission and external changes. European Review of Agricultural Economics 33: 562-590.

Ringe, N. (2009). Who Decides, And How?: Preferences, Uncertainty, And Policy Choice In The European Parliament. Oxford: Oxford University Press.

Sahrbacher, A., Balmann, A. and Sahrbacher, C. (2015). The political economy of capping direct payments: Applications in-and implications for-Germany. In J. F. M. Swinnen (ed), The Political Economy of the 2014-2020 Common Agricultural Policy: An Imperfect Storm2. Brussels: Centre for European Policy Studies, 277-306.

Shapley, L. S. and Shubik, M. (1969). On market games. Journal of Economic Theory 1: 9-25.

Swinbank, A. (2015). The WTO: no longer relevant for CAP reform? In J. F. M. Swinnen (ed), The Political Economy of the 2014-2020 Common Agricultural Policy: An Imperfect Storm. Brussels: Centre for European Policy Studies, 193-214.

Swinnen, J. F. M. (2008). The political economy of the Fischler reforms of the EU's Common Agricultural Policy: the perfect storm? In J. F. M. Swinnen (ed), The Perfect Storm-The Political Economy of the Fischler Reforms of the Common Agricultural Policy. Brussels: Centre for European Policy Studies, 135-166.

Swinnen, J. F. M. (2015a). The Political Economy of the 2014-2020 Common Agricultural Policy: An Imperfect Storm. Brussels: Centre for European Policy Studies, Rowman \& Littlefield International, Ltd.

Swinnen, J. F. M. (2015b). The political economy of the 2014-2020 Common Agricultural Policy: Introduction and key conclusions. In J. F. M. Swinnen (ed), The Political Economy of the 2014-2020 Common Agricultural Policy: An Imperfect Storm. Brussels: Centre for European Policy Studies, Rowman \& Littlefield International, Ltd., 1-30.

Westlake, M. (1994). A Modern Guide to the European Parliament. London: Pinter.

Whitaker, R. (2005). National parties in the European Parliament. European Union Politics 6: 5-28. 
పे

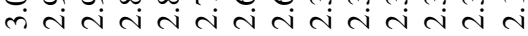

के

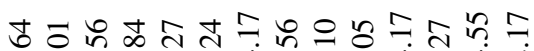

mirac

구 윤

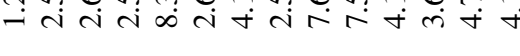

ஸิ

事

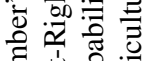

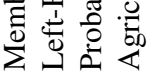

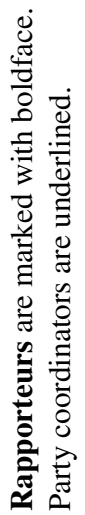

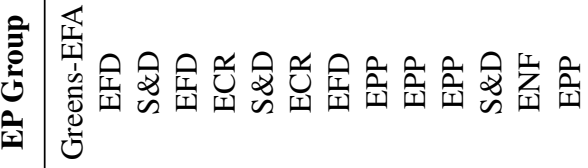

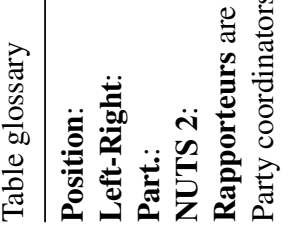

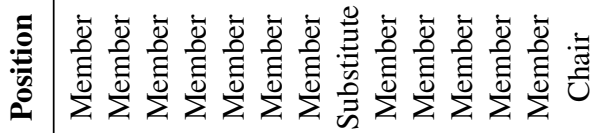

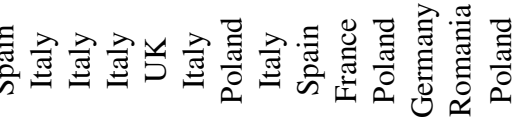

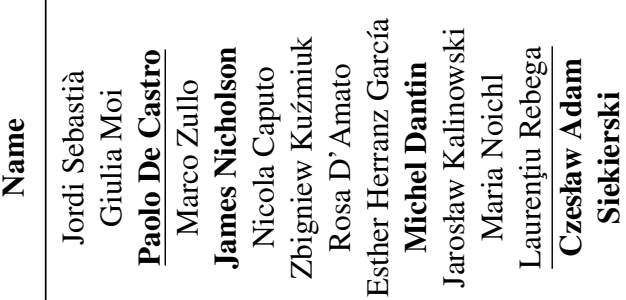




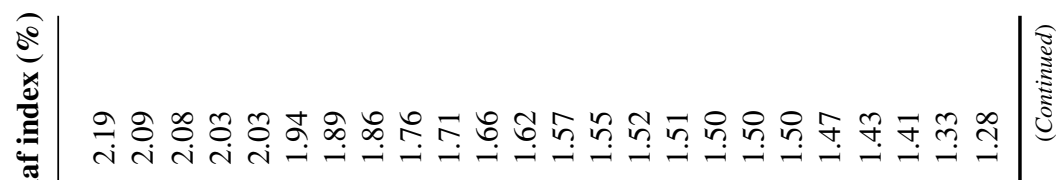

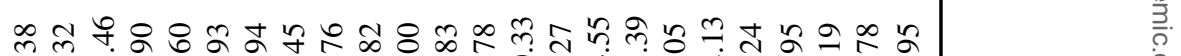

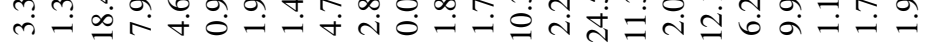

点

章

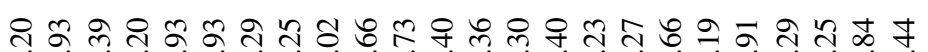
-

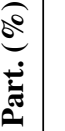

그으요

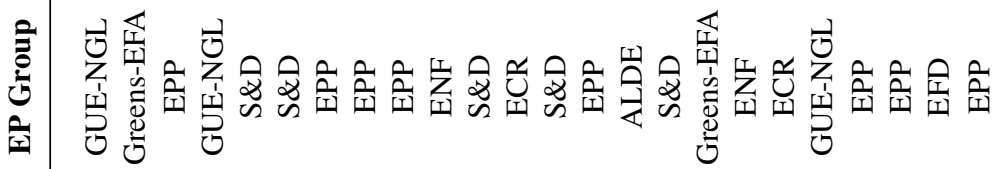

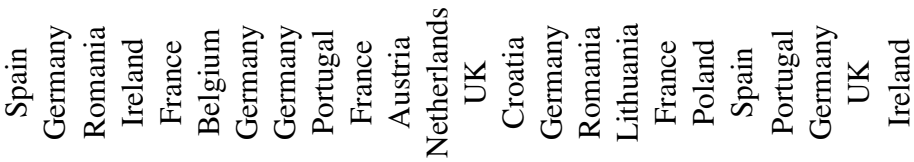

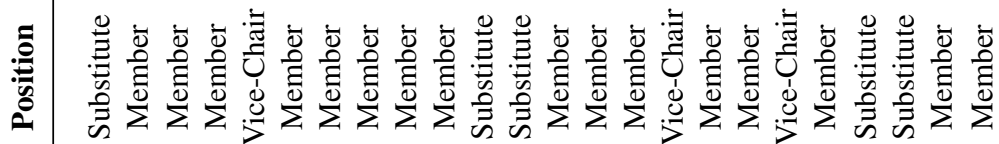

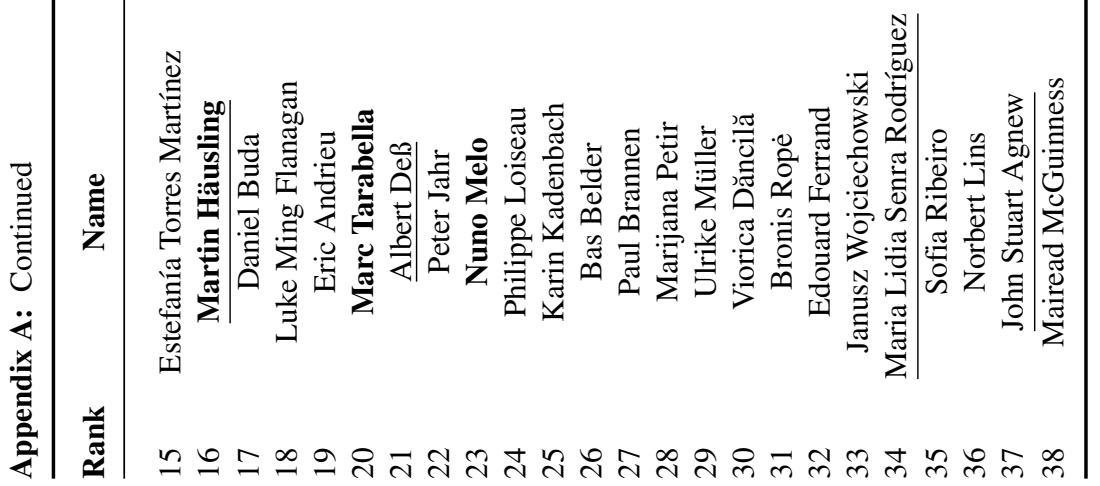




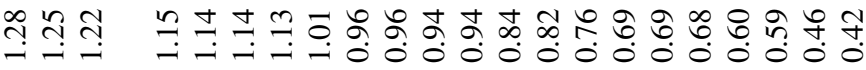

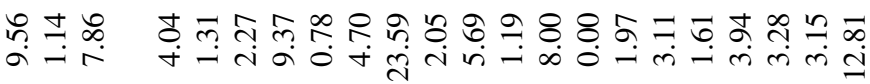

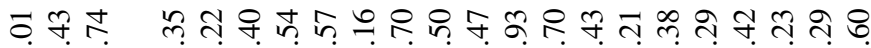

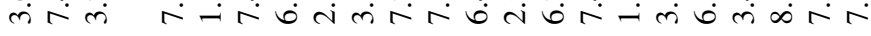

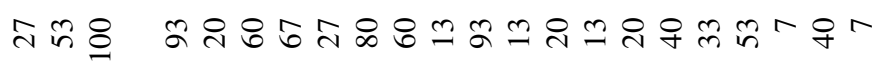

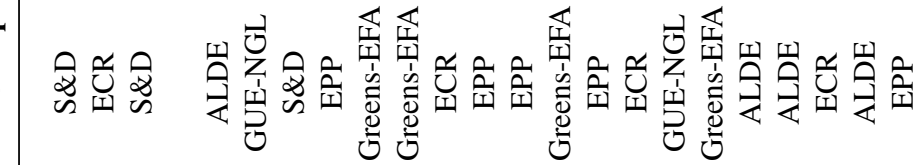

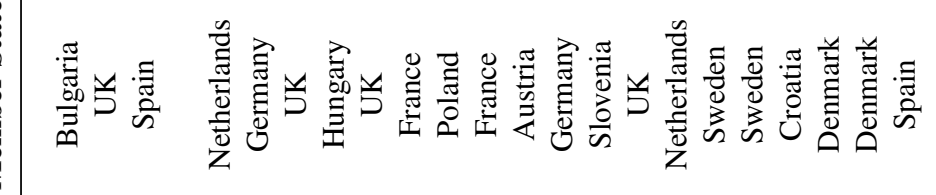

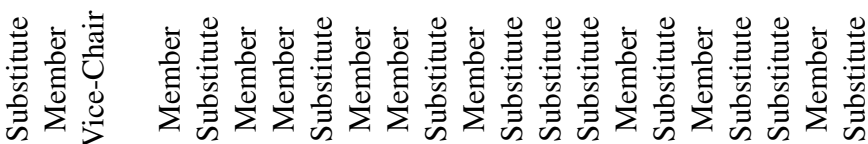

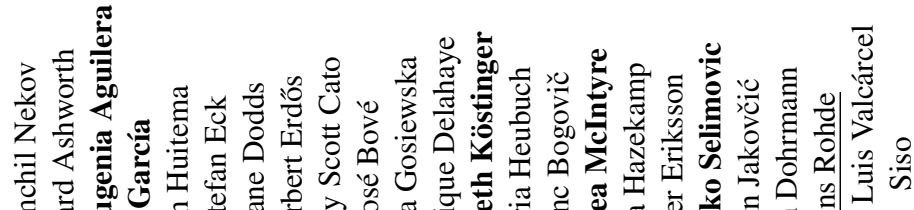

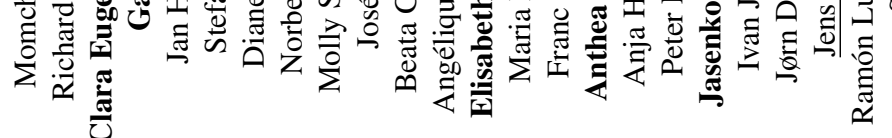




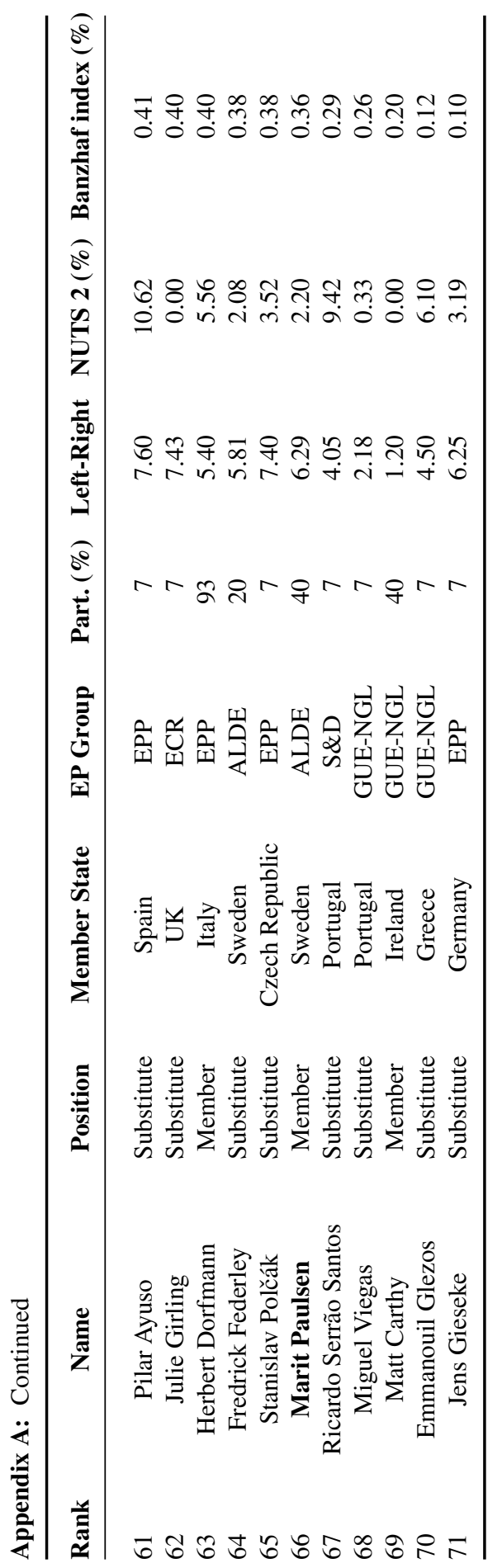


Appendix B.

\begin{tabular}{|c|c|c|c|c|c|c|c|c|c|}
\hline & \multicolumn{4}{|c|}{ 2014-19 term } & \multicolumn{4}{|c|}{ 2019-24 term } & \multirow[b]{2}{*}{ Change } \\
\hline & $\begin{array}{l}\text { Left-right } \\
\text { (1-left; } \\
\text { 10-right) }\end{array}$ & $\begin{array}{c}\text { Agricultural } \\
\text { employment } \\
\text { percentage 2015, } \\
\text { NUTS } 2 \text { level }\end{array}$ & Banzhaf & $\begin{array}{c}\text { member }(m) / \\
\operatorname{sub}(\mathrm{s})\end{array}$ & $\begin{array}{l}\text { Left-right } \\
\text { (1-left; } \\
\text { 10-right) }\end{array}$ & $\begin{array}{c}\text { Agricultural } \\
\text { employment } \\
\text { percentage } 2015 \text {, } \\
\text { NUTS } 2 \text { level }\end{array}$ & Banzhaf & $\begin{array}{c}\text { member }(m) / \\
\operatorname{sub}(s)\end{array}$ & \\
\hline Anja HAZEKAMP & 1.21 & $2.0 \%$ & $3.2 \%$ & $\mathrm{~m}$ & 1.62 & $2.0 \%$ & n.a. & s & n.a. \\
\hline $\begin{array}{l}\text { Bronis ROPÉ } \\
\text { Clara Eugenia }\end{array}$ & 3.27 & $11.4 \%$ & $2.3 \%$ & $\mathrm{~m}$ & 3.27 & $11.4 \%$ & $2.4 \%$ & $\mathrm{~m}$ & $0.1 \%$ \\
\hline AGUILERA & 3.74 & $7.9 \%$ & $1.5 \%$ & $\mathrm{~m}$ & 3.74 & $7.9 \%$ & $1.4 \%$ & $\mathrm{~m}$ & $-0.1 \%$ \\
\hline Daniel BUDA & 5.39 & $18.5 \%$ & $2.0 \%$ & $\mathrm{~m}$ & 6.05 & $18.5 \%$ & $3.6 \%$ & $\mathrm{~m}$ & $1.7 \%$ \\
\hline Eric ANDRIEU & 2.93 & $4.6 \%$ & $1.8 \%$ & $\mathrm{~m}$ & 3.25 & $4.6 \%$ & $1.3 \%$ & $\mathrm{~m}$ & $-0.5 \%$ \\
\hline Franc BOGOVIČ & 6.70 & $8.0 \%$ & n.a & s & 6.70 & $8.0 \%$ & n.a. & s & n.a. \\
\hline Fredrick FEDERLEY & 5.81 & $2.1 \%$ & n.a & s & 5.81 & $2.1 \%$ & n.a. & s & n.a. \\
\hline Herbert DORFMANN & 5.40 & $5.6 \%$ & $0.3 \%$ & $\mathrm{~m}$ & 5.40 & $5.6 \%$ & $0.2 \%$ & $\mathrm{~m}$ & $-0.1 \%$ \\
\hline Jan HUITEMA & 7.35 & $4.0 \%$ & $1.0 \%$ & $\mathrm{~m}$ & 7.35 & $4.0 \%$ & n.a. & s & n.a. \\
\hline Jarosław KALINOWSKI & 4.19 & $24.2 \%$ & $2.8 \%$ & $\mathrm{~m}$ & 4.19 & $24.2 \%$ & $3.9 \%$ & $\mathrm{~m}$ & $1.2 \%$ \\
\hline Luke Ming FLANAGAN & 1.20 & $7.9 \%$ & $3.1 \%$ & $\mathrm{~m}$ & 1.62 & $7.9 \%$ & $3.0 \%$ & $\mathrm{~m}$ & $-0.1 \%$ \\
\hline Mairead MCGUINNESS & 6.44 & $1.9 \%$ & $1.4 \%$ & $\mathrm{~m}$ & 6.44 & $1.9 \%$ & $1.7 \%$ & $\mathrm{~m}$ & $0.3 \%$ \\
\hline Marc TARABELLA & 2.93 & $0.9 \%$ & $2.3 \%$ & $\mathrm{~m}$ & 2.93 & $0.9 \%$ & n.a. & s & n.a. \\
\hline Maria NOICHL & 3.65 & $1.3 \%$ & $2.9 \%$ & $\mathrm{~m}$ & 3.65 & $1.3 \%$ & $2.3 \%$ & $\mathrm{~m}$ & $-0.6 \%$ \\
\hline Martin HÄUSLING & 2.93 & $1.3 \%$ & $2.4 \%$ & $\mathrm{~m}$ & 2.93 & $1.3 \%$ & $1.8 \%$ & $\mathrm{~m}$ & $-0.6 \%$ \\
\hline Matt CARTHY & 1.20 & $0.0 \%$ & $0.5 \%$ & $\mathrm{~m}$ & 2.79 & $0.0 \%$ & $2.0 \%$ & $m$ & $1.5 \%$ \\
\hline Norbert LINS & 6.25 & $1.2 \%$ & n.a & s & 6.25 & $1.2 \%$ & $2.3 \%$ & $\mathrm{~m}$ & n.a. \\
\hline Paolo DE CASTRO & 2.62 & $7.6 \%$ & $2.9 \%$ & $\mathrm{~m}$ & 2.62 & $7.6 \%$ & $2.2 \%$ & $\mathrm{~m}$ & $-0.7 \%$ \\
\hline Peter JAHR & 6.25 & $1.4 \%$ & $2.4 \%$ & $\mathrm{~m}$ & 6.25 & $1.5 \%$ & n.a. & s & n.a. \\
\hline Ulrike MÜLLER & 7.40 & $2.3 \%$ & $1.6 \%$ & $\mathrm{~m}$ & 7.40 & $2.3 \%$ & $2.2 \%$ & $\mathrm{~m}$ & $0.6 \%$ \\
\hline Zbigniew KUŹMIUK & 4.19 & $24.2 \%$ & $2.8 \%$ & $\mathrm{~m}$ & 7.70 & $24.2 \%$ & n.a. & s & n.a. \\
\hline
\end{tabular}

